\title{
Loss Severity Evaluation Using Grey Relational Analysis: A Case Study of Natural Disasters in Taiwan
}

\author{
Jun-Yuan Kuo ${ }^{1}$ and Yun-Chin Chen ${ }^{2, *}$ \\ ${ }^{\text {I}}$ Department of International Business, Kainan University, Kainan Road, Taoyuan, 33857, Taiwan, ROC \\ ${ }^{2}$ Department of Business Administration, De Lin Institute of Technology, Qingyun Road, New Taipei City, 23654, \\ Taiwan, ROC
}

\begin{abstract}
Taiwan is affected by three primary types of natural disasters: typhoons, earthquakes, and floods. Natural disasters in Taiwan can cause human causalities and loss of housing. Therefore, a method for evaluating the severity of losses caused by natural disasters would be beneficial for disaster management institutes in Taiwan when developing further supply chain management (SCM) strategies. To evaluate loss severity resulted from natural disasters in Taiwan, this study adopted grey relational analysis (GRA) to develop a method for evaluating the severity of losses caused by typhoons, earthquakes, and floods based on four indicators: human casualties, loss of housing, disaster relief personnel, and disaster relief equipment. According to the study results, the proposed GRA method is appropriate for evaluating the severity of losses caused by typhoons, earthquakes, and floods. The proposed GRA method is effective for evaluating the severity of loss resulting from natural disasters in Taiwan, which can serve as a reference for disaster management institutes to develop supply strategies in the future.
\end{abstract}

Keywords: Grey Relation Analysis (GRA), Loses Caused by Natural Disasters (LCND), Supply Chain Management (SCM).

\section{INTRODUCTION}

Natural disasters in Taiwan lead to human casualties and substantial loss of housing and property, requiring the mobilization of considerable human resources and equipment to implement disaster relief efforts. An effective method for evaluating the severity of loss caused by natural disasters in Taiwan can serve as a reference for disaster management institutes developing future supply chain management (SCM) strategies. Therefore, the evaluation of the severity of losses caused by natural disasters in Taiwan is an essential topic. In this study, grey relational analysis (GRA) was employed to evaluate and compare the severity of loss caused by typhoons, earthquakes, and floods. The research data were obtained from Environmental Protection Administration, Executive Yuan, R.O.C. (Taiwan) [1], and the National Fire Agency, Ministry of the Interior, Executive Yuan, R.O.C. (Taiwan) [2]. The results of this study can serve as a reference for disaster management institutes in establishing goals and developing supply chain management (SCM) strategies.

\section{MATERIALS AND METHODS}

GRA theory was proposed by Deng [3], and it has been widely applied in various topics. Shao and Li [4] applied the

\footnotetext{
*Address correspondence to this author at the Department of Business Administration, De Lin Institute of Technology, Qingyun Road, New Taipei City, 23654,Taiwan, ROC; Tel: +886 922201151; Fax: +886 3341 2175;
} E-mail: citysching@yahoo.com.tw
GRA to evaluate the heavy metal pollution. Chen [5] used the GRA to understand the employee training quality. Geum et al. [6] used the GRA to analyze the service failure diagnosis. Xiao et al. [7] utilized the GRA to know about the web site service quality. Tseng [8] has applied the GRA to understand the environmental knowledge management. Kung and Wen [9] adopted the GRA to analyze the financial performance. Golmohammadi and Mahour [10] applied the GRA to know about the evaluation and selection of suppliers. Lee and Lin [11] adopted the GRA to know about the evaluation of energy performance of office buildings. Zhang [12] applied the GRA to understand the venture capital investment. Adopting the procedures proposed by Wen et al. [13], this study used GRA to evaluate the severity of loss resulting from natural disasters in Taiwan.

\subsection{Grey Relation Analysis}

The original data of the indicators for evaluating the severity of losses caused by natural disasters (i.e., typhoons, floods, and earthquakes) satisfy comparability requirements. Consequently, this study used the original data to conduct GRA and established a reference sequence and a comparison sequence.

Using the equation 1 , the size of the difference sequences of the evaluation indicators can be calculated.

$$
\Delta \mathrm{Qi}(\mathrm{k})=|\mathrm{G} 0(\mathrm{k}), \mathrm{Gi}(\mathrm{k})|
$$


Then, the maximal and minimal difference sequences of the evaluation indicators were calculated. The obtained $\mathrm{Z}$ weight value was 0.5 .

The grey relational coefficient of the evaluation indicators can be calculated using the following equation 2 .

$\mathrm{Y}(\mathrm{Gi}(\mathrm{k}), \mathrm{Gj}(\mathrm{k}))=(\Delta \min +\mathrm{Z} \Delta \max ) /(\Delta \mathrm{ij}(\mathrm{k})+\mathrm{Z} \Delta \max ) \quad$ Eq. (2)

The grey relational grades of the indicators for evaluating the severity of loss caused by typhoons, floods, and earthquakes were calculated. The grey relational orders of the aforementioned indicators were sorted.

\section{RESULTS}

After determining the severity of loss caused by natural disasters in Taiwan, Table 1 was compiled. Table 1 shows the 2011-2013 data for evaluating the severity of loss caused by typhoons, floods, and earthquakes. According to the database of the Environmental Protection Administration, Executive Yuan, R.O.C. (Taiwan) [1], and the National Fire Agency, Ministry of the Interior, Executive Yuan, R.O.C. (Taiwan) [2], human casualties, loss of housing, disaster relief personnel, and disaster relief equipment are the primary indicators $[1,2]$ for evaluating the severity of loss resulting from natural disasters.

The framework developed by Wen et al. [13] was adopted to calculate the severity of loss caused by natural disasters in Taiwan in 2011. The evaluation results are presented below. Subsequently, the same calculation was performed for 2012-2013, also according to Wen et al. [13]. Table 2 shows the evaluation results. The software used in this study was obtained from the CD in the publication by Wen et al. [13].

Step 1: The original data of the indicators for evaluating the losses caused by natural disasters (i.e., typhoons, floods, and earthquakes) satisfy comparability requirements. Therefore, the original data were used to conduct the GRA.

Reference sequence 0.4, 2.2, 9,791.6, 1,693.2

Comparison sequence 0.4, 2.2, 9,791.6, 1,693.2

$$
\begin{aligned}
& 0.0,0.0,281.4,9.0 \\
& 0.0,0.0,0.0,0.0
\end{aligned}
$$

Step 2: The formula $\Delta Q_{i}(k)=\left|G_{0}(k)-G_{i}(k)\right|$ was used to calculate the sizes of the different sequences of the indicators for evaluating the losses caused by natural disasters. The calculation results are presented as follows.

$$
\begin{aligned}
& \Delta Q_{1}=(0.0,0.0,0.0,0.0) \\
& \Delta Q_{2}=(0.4,2.2,9,510.2,1,684.2) \\
& \Delta Q_{3}=(0.4,2.2,9,791.6,1,693.2)
\end{aligned}
$$

Step 3: The maximal and minimal difference sequences of the evaluation indicators were calculated.

Maximal difference: 9,791.6

Minimal difference: 0.0

Step 4: The obtained $Z$ value $=0.5000$.

Step 5: Using the formula

$Y\left[G_{i}(k), G_{j}(k)\right]=(\Delta \min +\mathrm{Z} \Delta \max ) /(\Delta i j(k)+\mathrm{Z} \Delta \max )$, the grey relational coefficients of the evaluation indicators were calculated. The results are presented as follows.

$Y\left(G_{0}(1), G_{1}(1)\right)=1.0000, Y\left(G_{0}(2), G_{1}(2)\right)=1.0000, Y\left(G_{0}(3)\right.$, $\left.G_{1}(3)\right)=1.0000, Y\left(G_{0}(4), G_{1}(4)\right)=1.0000, Y\left(G_{0}(1), G_{2}(1)\right)=$ $0.9999, Y\left(G_{0}(2), G_{2}(2)\right)=0.9996, \mathrm{Y}\left(G_{0}(3), G_{2}(3)\right)=0.3398$, $Y\left(G_{0}(4), G_{2}(4)\right)=0.7440$,

$Y\left(G_{0}(1), G_{3}(1)\right)=0.9999, Y\left(G_{0}(2), G_{3}(2)\right)=0.9996, Y\left(G_{0}(3)\right.$, $\left.G_{3}(3)\right)=0.3333, Y\left(G_{0}(4), G_{3}(4)\right)=0.7430$

Step 6: The grey relational grades were calculated for the indicators for evaluating the severity of loss caused by typhoons, floods, and earthquakes. Given an equal weight value $\beta=1 / 4$, the following grades were obtained:

$Y\left(G_{0}, G_{1}\right)=1.0000$ (typhoons), $Y\left(G_{0}, G_{2}\right)=0.7708$ (floods), and $Y\left(G_{0}, G_{3}\right)=0.7690$ (earthquakes).

Step 7: The grey relational orders of the indicators for

\begin{tabular}{|c|c|c|c|c|c|c|c|c|c|c|c|}
\hline Year 2011 & Typhoons & Floods & $\begin{array}{l}\text { Earth- } \\
\text { quakes }\end{array}$ & Year 2012 & Typhoons & Floods & $\begin{array}{l}\text { Earth- } \\
\text { quakes }\end{array}$ & Year 2013 & Typhoons & Floods & $\begin{array}{l}\text { Earth- } \\
\text { quakes }\end{array}$ \\
\hline Casualties (Persons) & 0.4 & 0 & 0 & $\begin{array}{c}\text { Casualties } \\
\text { (Persons) }\end{array}$ & 5 & 1.73 & 0 & $\begin{array}{c}\text { Casualties } \\
\text { (Persons) }\end{array}$ & 28.6 & 0 & 61 \\
\hline Loss of Housing & 2.2 & 0 & 0 & Loss of Housing & 20.57 & 0.18 & 0 & Loss of Housing & 12 & 0 & 1 \\
\hline $\begin{array}{c}\text { Disaster relief } \\
\text { personnel (Number of } \\
\text { Personnel) }\end{array}$ & 9791.6 & 281.4 & 0 & $\begin{array}{l}\text { Disaster relief } \\
\text { personnel } \\
\text { (Number of } \\
\text { Personnel) }\end{array}$ & 21144.85 & 2504.45 & 0 & $\begin{array}{c}\text { Disaster relief } \\
\text { personnel } \\
\text { (Number of } \\
\text { Personnel) }\end{array}$ & 21506.16 & 1731 & 339.5 \\
\hline $\begin{array}{c}\text { Disaster relief } \\
\text { equipment }\end{array}$ & 1693.20 & 9 & 0 & $\begin{array}{c}\text { Disaster relief } \\
\text { equipment }\end{array}$ & 7154.85 & 925 & 0 & $\begin{array}{c}\text { Disaster relief } \\
\text { equipment }\end{array}$ & 7920.33 & 410 & 65.5 \\
\hline
\end{tabular}
evaluating the severity of loss caused by typhoons, floods, and earthquakes were sorted from the highest to the lowest value:

Table 1. Original data of the evaluation indicators for the severity of losses caused by natural disasters in Taiwan (2011-2013).

Source: Environmental Protection Administration, Executive Yuan, R.O.C. (Taiwan) [1], and the National Fire Agency, Ministry of the Interior, Executive Yuan, R.O.C. (Taiwan) [2]. 
Table 2. Evaluation results on severity of loss caused by natural disasters in Taiwan (2011-2013).

\begin{tabular}{|c|c|c|c|c|c|c|c|c|c|c|c|}
\hline Year & Disaster & $\begin{array}{c}\text { Grey Rela- } \\
\text { tional Value }\end{array}$ & $\begin{array}{c}\text { Grey Rela- } \\
\text { tional Order }\end{array}$ & Year & Disaster & $\begin{array}{c}\text { Grey Rela- } \\
\text { tional Value }\end{array}$ & $\begin{array}{c}\text { Grey Rela- } \\
\text { tional Order }\end{array}$ & Year & Disaster & $\begin{array}{c}\text { Grey Rela- } \\
\text { tional Value }\end{array}$ & $\begin{array}{l}\text { Grey Rela- } \\
\text { tional Order }\end{array}$ \\
\hline \multirow{3}{*}{2011} & Typhoons & 1.0000 & 1 & \multirow{3}{*}{2012} & Typhoons & 1.0000 & 1 & \multirow{3}{*}{2013} & Typhoons & 0.9992 & 1 \\
\hline & Floods & 0.7708 & 2 & & Floods & 0.7472 & 2 & & Floods & 0.7317 & 2 \\
\hline & Earthquakes & 0.7690 & 3 & & Earthquakes & 0.7318 & 3 & & Earthquakes & 0.7266 & 3 \\
\hline
\end{tabular}

$Y\left(G_{0}, G_{1}\right)=1.0000$ (typhoons) $>Y\left(G_{0}, G_{2}\right)=0.7708$ (floods) $>Y\left(G_{0}, G_{3}\right)=0.7690$ (earthquakes)

As shown in Table 2, typhoons caused the most serious losses from 2011 to 2013, followed by floods, and then earthquakes. Therefore, natural disaster management institutes in Taiwan must consider typhoons as a priority issue and establish comprehensive disaster prevention and relief strategies for typhoon events.

\section{DISCUSSION}

The analysis results indicate that typhoons would cause the most serious losses, followed by floods, and then earthquakes. As shown in Table 2, the grey relational value (i.e., the severity of loss caused by natural disasters) of typhoons was the highest for all three years $(1.0000,1.000$, and $0.9992)$, followed by floods $(0.7708,0.7472$, and 0.7317$)$, and then earthquakes $(0.7690,0.7318$, and 0.7266$)$.

Table 2 further shows that typhoons caused the most serious loss and damage to the structure and exterior of houses. Therefore, designing wind-resistant housing structures should be considered to mitigate the level of damage caused to houses. Moreover, protection measures should be implemented to reduce the number of human casualties by urging people who live in easily damaged homes to relocate to safe areas as soon as possible when disasters occur.

The damage caused by floods is severe and second only to that caused by typhoons. Although the Taiwanese government has implemented numerous flood control measures, heavy rainfall frequently leads to flooding, indicating that flood prevention measures are inadequate, particularly regarding supply capacity.

Earthquakes in Taiwan also lead to heavy losses. Although such losses were not as serious as those caused by typhoons and floods, caution is nonetheless necessary. Earthquakes did not occur frequently over the past three years and did not lead to significant damage. However, comprehensive measures must be developed and adequate equipment for disaster relief efforts must be provided.

\section{CONCLUSION}

This study adopted a GRA method to evaluate the losses caused by natural disasters in Taiwan. Research data on the severity of loss resulting from the natural disasters in Taiwan were obtained to verify the effectiveness of the proposed method.
The findings of this study indicate that typhoons caused the most serious losses in Taiwan, followed by floods, and then earthquakes. The severity of loss caused by natural disasters shows that typhoons indeed cause the most substantial damage. Moreover, the data of human casualties, loss of housing, disaster relief personnel, and disaster relief equipment demonstrate that the severity of loss caused by typhoons is extremely high.

The results of this study can assist disaster management institutes in identifying problems that lead to severe losses by providing comparable evaluation results based on the three primary natural disasters affecting Taiwan, thereby serving as a reference for disaster management institutes to improve their supply chain management (SCM) strategies.

\section{CONFLICT OF INTEREST}

The authors confirm that this article content has no conflict of interest.

\section{ACKNOWLEDGEMENTS}

Declared none.

\section{REFERENCES}

[1] Environmental Protection Administration, Executive Yuan, R.O.C. (Taiwan), 2014 Annual Statistical Report on Environmental Protection R.O.C., 2014. 2014 [http://www.epa.gov.tw/np.asp? ctNode $=31088 \& \mathrm{mp}=$ epa].

[2] National Fire Agency, Ministry of the Interior, Executive Yuan, R.O.C. (Taiwan), Disaster Contingency Disposal Report on National Fire Agency, R.O.C., 2014. [http://www.nfa.gov.tw/main/ List.aspx? ID = \&MenuID=342]

[3] J. L. Deng, "Control problems of grey systems," Syst. Control. Lett., vol. 1, no. 5, pp. 288-294, 1982.

[4] X. Shao, and X. Li, "Soil heavy metal pollution evaluation using grey relational analysis," Energy Proc., vol. 11, pp. 4878-4882, 2011.

[5] B. J. Chen, "Grey relational analysis on the quality training of employees," Energy Proc., vol. 13, pp. 10068-10074, 2011.

[6] Y. J. Geum, Y. G. Cho, and Y. T. Park, "A systematic approach for diagnosing service failure: Service-specific FMEA and grey relational analysis approach," Math. Comput. Model, vol. 54, pp. 31263142, 2011.

[7] X. C. Xiao, X. Q. Wang, K. Y. Fu, and Y. J. Zhao," Grey relational analysis on factors of the quality of web service," Phys. Proc., vol. 33, pp. 1992-1998, 2012.

[8] M. L. Tseng, "Using linguistic preferences and grey relational analysis to evaluate the environmental knowledge management capacity," Expert. Sys. Appl,, vol. 37, pp.70-81, 2010.

[9] C. Y. Kung, and K. L. Wen, "Applying grey relational analysis and grey decision-making to evaluate the relationship between company attributes and its financial performance - a case study of venture capital enterprises in Taiwan," Decision Support Syst., vol. 43, pp. 842-852, 2007. 
[10] D. Golmohammadi, and M. P. Mahour, "Developing a grey-based decision-making model for supplier selection," Int. J. Prod. Econ., vol. 137, pp.191-200, 2012.

[11] W. S. Lee, and Y. C. Lin, "Evaluating and ranking energy performance of office buildings using grey relational analysis," Energy, vol. 36, pp.2551-2556, 2011.
[12] X. B. Zhang, "Venture capital investment base on grey relational theory," Phys. Proc., vol. 33, pp.1825-1832, 2012.

[13] K. L. Wen, I. N Huang, W. C. Chang, T. C. Chang, M. L. Yu, and C. J. Lai, Methods and Applications of the Grey Relational Model, Gau Lih HandBook Co., Ltd, University Science, 2003.

Received: September 16, 2014

Revised: December 23, 2014

Accepted: December 31, 2014

(C) Kuo and Chen; Licensee Bentham Open.

This is an open access article licensed under the terms of the (https://creativecommons.org/licenses/by/4.0/legalcode), which permits unrestricted, non-commercial use, distribution and reproduction in any medium, provided the work is properly cited. 